\title{
Vertigo Can Give Notice of Herpes Simplex Virus Encephalitis
}

\author{
Kiarash Azimzadeh ${ }^{1}$, Farinaz Tabibian ${ }^{1}$, and Parisa Emami Ardestani ${ }^{1}$ \\ ${ }^{1}$ Isfahan University of Medical Sciences
}

March 7, 2022

\begin{abstract}
Identification of uncommon clinical features of Herpes simplex virus encephalitis (HSVE) reduces its sequels and mortality. Vertigo has not been reported as the only neurologic presentation of HSVE. This article describes a patient with vertigo as the first neurologic symptom of HSVE and explains possible pathophysiological mechanisms of this manifestation.
\end{abstract}

\section{Hosted file}

Main Text.docx available at https://authorea.com/users/463903/articles/558913-vertigo-cangive-notice-of-herpes-simplex-virus-encephalitis

\section{Hosted file}

Figure 1.docx available at https://authorea.com/users/463903/articles/558913-vertigo-cangive-notice-of-herpes-simplex-virus-encephalitis 